\title{
Nutrition Awareness Counseling to Support Indonesia Ready for New Normal
}

\author{
Latifahtur Rahmah a), Irra Chrisyanti Dewi, and Ryan Yeremia Iskandar \\ Program Studi D3 Seni Kuliner. Ottimmo International Culinary Academy and Patisserie, Surabaya
Indonesia
\[ \begin{array}{l}\text { a)Corresponding Author: Iatifahturrahmah@ottimmo.ac.id }\end{array} \]
}

\begin{abstract}
Proper nutrition and adequate water are essential during the COVID-19 outbreak. People who eat a balanced diet tend to be healthier with a stronger immune system. The risk of chronic diseases and infectious diseases is lower, so there needs to be an outreach to the public about nutrition awareness to support Indonesia to be ready for the new normal. Nutrition education serves to create awareness and spread knowledge. The implementation of this counseling consists of the delivery of material and questions and answers. The material consists of: 1) nutrition conscious behavior that focuses on balanced nutrition guidelines and the role of vitamins and minerals in increasing the body's immune system; 2) Nutrition conscious behavior that focuses on the role of essential fats (EPA and DHA) in increasing the body's immune system; 3) Nutrition conscious behavior that focuses on processing food with balanced nutrition. A series of outreach activities have been well organized. Most of the counseling participants felt that community service activities were carried out through counseling about nutrition awareness to support indonesia ready for new normal. This nutrition awareness counseling is very useful to prepare nutrition for the Covid-19 pandemic.
\end{abstract}

Keywords: Counseling, Nutrition Awareness, New Normal

\section{INTRODUCTION}

Centers for Disease Control and Prevention (2020) Explain the meaning of Coronavirus (COVID-19) is a disease caused by a virus that can spread from person to person. The virus that causes COVID-19 is a new corona virus that has spread throughout the world. Symptoms of COVID-19 can range from mild (or asymptomatic) to severe illness. The first human case of COVID-19, the disease caused by the novel coronavirus that causes COVID-19, later named SARS-CoV-2, was first reported by officials in Wuhan City, China, in December 2019. Retrospective investigation by Chinese authorities have identified human cases with onset of symptoms in early December 2019. Many of the initial patients were stall owners, market employees, or regular visitors to this market (Sheng, 2020).

There are two main routes of transmission of the COVID-19 virus: respiratory and contact. Respiratory droplets come from coughing or sneezing of an infected person. Anyone who has close contact with someone who has symptoms of respiratory problems (such as sneezing and coughing) is at risk of exposure to infected droplets. One of these sparks may fall on a surface where the virus can survive, for that the environment around an infected individual can be a source of transmission (called contact transmission). It is not yet certain how long the COVID-19 virus can survive on the surface of objects, but it is likely to have the same characteristics as other types of corona virus. There was recently a review of the resistance of the coronavirus to surfaces which showed various findings ranging from two hours to nine days. Survival time is highly dependent on many factors, including the surface material, temperature, humidity, and the specific type of virus. The same review also mentions that an effective way to kill viruses in one minute can be done with ordinary disinfectants, such as $70 \%$ alcohol or with sodium hypochlorite (WHO and UNICEF 2020).

The Food and Drug Supervisory Agency as a government agency that has a mandate in food safety and quality supervision issues Circular Letter Number: HK.02.02.1.2.04.20.12 of 2020 concerning Efforts to Maintain the Availability of Quality Medicines and Foods during the Period of Certain Emergency Situations of Epidemic Disasters COVID-19 in Indonesia. Following up on 
the circular, to ensure the availability of safe and quality processed food and to reduce the spread of COVID-19, guidelines are needed for food business actors, particularly related to the production and distribution process as a guide protocol to prevent the spread of COVID-19. The application of these guidelines applies during the COVID-19 pandemic which is set by the government as a public health emergency response period (BPOM, 2020).

Infection Prevention and Control (IPC) is critical to managing this risk. The IPC program supports avoidable and lifesaving infection prevention. The way to prevent the corona virus is to practice hand hygiene. It is the best way to prevent the spread of germs in the health and community environment. Because our hands are the main tool to work as health workers and are the key link in the chain of transmission. The next method of prevention is to use Personal Protective Equipment (PPE) which is clothing or special equipment worn by employees for protection against infectious materials (IPPF, 2019).

Meanwhile, with Indonesia's very limited capacity in dealing with this all-new virus, where developed countries with strong health systems are also overwhelmed, it is necessary to realize that a new life can survive side by side, let alone make peace with Covid-19. A new normal life is a life where humans are always faced with the threat of Covid-19 (Muhyiddin 2020). Understanding the new normal is explained in more detail Habibi (2020) said that new Normal is a condition and or social habit of the community or individual behavior that appears after Covid19 is over. Like New Normal, Old Normal is the social condition of society before the Covid-19 pandemic. Hopefully this new normal does not make the social community a new group that loses its old social.

Muhyiddin (2020) explained that the government provides guidelines on how the new normal life must be carried out by the community according to 7 norms, namely: (1) Washing hands; (2) Avoid touching the face Avoid touching the face area; (3) Apply coughing and sneezing etiquette when coughing or sneezing because the body will expel the virus from the body; (4) Wear a mask when going out or interacting with other people; (5) Maintain social distancing to avoid exposure to the virus; (6) independent solutions (done for those who feel unwell, such as experiencing several symptoms of illness, namely fever, cough, runny nose, sore throat or shortness of breath); and (7) Maintaining health by maintaining physical health, basking in the morning sun, eating nutritious food, and doing light exercise.

Proper nutrition and adequate water are essential during the COVID-19 outbreak. People who eat a balanced diet tend to be healthier, with a stronger immune system and a lower risk of chronic disease and infectious disease. People should eat a variety of fresh and unprocessed foods every day to get the vitamins, minerals, dietary fiber, protein and antioxidants that your body needs. Drink enough water. Avoid sugar, fat and salt to significantly lower the risk of being overweight, obese, heart disease, stroke, diabetes and certain types of cancer (WHO, 2020). Good nutrition is very important before during and after infection. Infection affects the body especially when it causes fever, the body needs extra energy and nutrients. Therefore, maintaining a healthy diet is very important during the COVID-19 pandemic. While no food or dietary supplement can prevent COVID-19 infection, maintaining a healthy diet is an important part of supporting a strong immune system (FAO, 2020). According to Waly (2018) nutrition science is the basic idea for understanding human nutrition and aspects of food nutrition education. to the community is considered an evidence-based intervention that uses a participatory development approach and community-based empowerment for primary prevention of chronic disease. Communications such as nutrition counseling serve to create awareness, spread knowledge, and enable people to change their practices. Nutrition education is needed to promote healthy eating between and within countries.

\section{METHOD}

This community service activity is held on September 11,2020 , at $14.00-16.00$, located on the 2nd Floor of the OTTIMMO International Culinary and Patisserie Academy. The implementation of community service consists of 3 stages, namely the preparation stage and the implementation stage. The preparation stage consists of: 1) Schedule preparation stage; 2) The 
stage of making the material; and 3) Flyer Making. At the implementation stage is the delivery of material and questions and answers. The materials consist of 1) nutrition conscious behavior that focuses on balanced nutrition guidelines and the role of vitamins and minerals in increasing the body's immune system; 2) Nutrition conscious behavior that focuses on the role of essential fats (EPA and DHA) in increasing the body's immune system; 3) Nutrition conscious behavior that focuses on food processing with balanced nutrition.

The last stage of this activity is the evaluation stage aimed at live zoom participants. The evaluation stage is carried out through the google form media which contains questions to test the level of understanding of the live zoom participants on the material presented.

\section{RESULTS}

Activity counseling on nutrition awareness to support Indonesia to be ready for the new normal was attended by 229 participants from various regions in Indonesia. In addition, various institutions and professions were participated in, ranging from students, civil workers to state civil servants. The presentation of the extension is arranged by the moderatorLatifahtur Rahmah, S.pd, M.Pd. Counseling was delivered by: 1) Martalena Br. Purba, MCN, PhD, RD (Dietisien RSUP dr. Sardjito Yogyakarta); 2) - Nurul Azizah Choiriyah, S.TP, M.Sc. (OTTIMMO academic lecturer); 3) Chef Ryan Yeremia Iskandar, SS (Practitioner Lecturer at OTTIMMO). In order to get maximum results, the researcher made an extension schedule with the schedule in table 1 in the Appendix.

'WHO (2004) explains Nutrition is a fundamental pillar of human life, health and development throughout the life span. From the early stages of fetal development, at birth, through infancy, childhood, adolescence, and beyond into adulthood and old age, proper food and good nutrition are essential for survival, physical growth, mental development, performance and productivity, health and welfare of beings. It is an important foundation of human and national development. People everywhere, throughout their lives, have the opportunity to achieve and maintain the highest attainable level of health. This is not possible if there is hunger and malnutrition.

Choi et al (2008) explained that children with higher nutritional knowledge or with appropriate nutritional attitudes seemed to have good eating behavior. A positive correlation between nutritional knowledge and dietary behavior has been reported in many studies at home and abroad, and nutritional knowledge influences eating levels and dietary behavior that emphasizes nutrition. It is considered that nutrition education programs for children and parents are needed not only to obtain correct nutrition knowledge. but also to promote positive dietary behavior and willingness to practice balanced nutrition and to encourage changes in dietary behavior for such improvement, because nutrition knowledge, nutrition attitudes, and dietary behavior are interrelated.

It is important to raise awareness of the nutrients contained in food in relation to its role in maintenance, growth, reproduction, health and disease prevention in humans. Proper nutrition is important for a variety of reasons, including optimal cardiovascular function, muscle strength, respiratory ventilation, protection from infection, wound healing, and psychological well-being. In addition, it helps prevent nutrition-related diseases through a diet containing appropriate amounts of dietary constituents, such as carbohydrates, proteins, fats, vitamins, minerals, and water, which are necessary for the formation and defense of the body, energy supply, and regulatory functions.(Eze et al, 2017)

Our bodies need enough of the right foods to give us the energy to grow, learn, work, and stay healthy. Children under the age of two have special needs because their bodies grow and change rapidly, even before birth. Pregnant and lactating women also need to eat well for their own health and that of their babies. Health and balanced nutrition guidelines are closely related. Well-nourished children are more likely to recover from serious illnesses than malnourished children. Serious or recurring illnesses such as malaria or diarrhea can increase a child's chances of becoming malnourished. School children and adults who suffer from micronutrients (vitamins and minerals) or other nutritional deficiencies may feel tired and struggle to work hard and are prone to poor health. In adults, this may make it difficult for them 
to provide for their families. Similarly, adults who are very overweight are more likely to have certain types of serious health problems. Balanced nutrition is important for everyone's health and well-being (IFRC, 2013).

Regulation of the Minister of Health of the Republic of Indonesia number 41 of 2014 explains that balanced nutrition guidelines must consist of a daily food composition that contains nutrients in the types and amounts that are in accordance with the body's needs. By paying attention to the principles of food diversity, physical activity, clean living behavior and monitoring body weight regularly in order to maintain a normal weight to prevent nutritional problems(Menteri Kesehatan, 2014). There are 10 guidelines for balanced nutrition in Indonesia by the Ministry of Health of the Republic of Indonesia as follows: 1) Get used to eating a variety of staple foods; 2) Limit consumption of sweet, salty, and fatty foods; 3) Do adequate physical activity and maintain ideal body weight; 4) Get used to eating side dishes that contain high protein; 5) Wash hands with soap and running water; 6) Get used to breakfast; 7) Get used to drinking enough and safe water; 8) Eat lots of fruits and vegetables; 9) Get used to reading labels on food packaging; 10) Be grateful and enjoy a variety of foods.

Nutrient-based vitamin and mineral recommendations include micronutrient composition and bioavailability in food, distribution of food intake by population groups, relevant micronutrient deficiencies and excesses, food supply and excess. Consumption of foods rich in micronutrient vitamins and beverages, namely: 1) Vegetables, fruits, nuts; 2) Breeding of soil, seeds, plants and animals; 3) Food fortification; 4) New food variety (WHO, 2004). FAO (2020) consume a variety of foods in each type of diet to ensure adequate intake of essential nutrients. Eat lots of fruits and vegetables. Fresh fruits and vegetables provide many of the vitamins and minerals as well as the fiber we need for a healthy diet. To limit your trips to the market or supermarket, in addition to fresh fruit and vegetables, you can also buy frozen or canned fruit and vegetables. These fruits and vegetables also contain vitamins and minerals. However, in the canning and processing of these products, other ingredients such as sugar, salt, or preservatives are sometimes added. Be sure to read the label so you can choose the best option for you and your family to limit your intake of these ingredients.

Tsoupras and Zabetakis (2020) explains that the role of nutrition in supporting the immune system is well established. Numerous mechanistic and clinical data indicate that vitamins, including vitamins $\mathrm{A}, \mathrm{B} 6, \mathrm{~B} 12, \mathrm{C}, \mathrm{D}, \mathrm{E}$, and folate; trace elements, including zinc, iron, selenium, magnesium, and copper; and the omega-3 fatty acids eicosapentaenoic acid and docosahexaenoic acid play important and complementary roles in supporting the immune system. Inadequate intake and nutritional status are widespread, leading to decreased resistance to infection and a consequent increase in disease burden. Against this background, the following conclusions were made: (1) supplementation with the above micronutrients and omega-3 fatty acids is a safe, effective, and inexpensive strategy to help support optimal immune function; (2) supplementation above the Recommended Dietary Allowance (RDA), but within the recommended upper safety limits, for certain nutrients such as vitamins $C$ and $D$ guaranteed; and (3) public health officials are encouraged to include nutrition strategies in their recommendations to improve public health.

Vitamins perform various functions in our body and one of them is to increase the immune response against pathogens. Immunity provides protection to life in three main ways, namely the skin response, the cellular response, and the humoral immune response. Both the quality and quantity of vitamins in the body enhance the process of systematic immunity by regulating lymphocyte, antibody and cytokine formation. In this review, we will summarize the role of water-soluble and fat-soluble vitamins for enhancing immune function. Vitamins $A$, $C$, and E mainly help improve the protective function of the skin epithelium. Except for vitamin $C$, all vitamins are claimed to be essential for antibody production. Most vitamins are applied in our body to produce a cell-mediated response with the production of cytokines and lymphocytes (Farhan Aslam et al, 2017).

WHO (2004) describes if a person can not meet the intake of vitamins and minerals, can use supplements. Supplementation refers to the periodic administration of nutritional 
pharmacological preparations as capsules or tablets, or by injection when substantial or immediate benefit is required for at-risk groups. As stipulated at the International Conference on Nutrition, nutritional supplementation should be limited to vulnerable groups who cannot meet their nutritional needs through food (e.g. women of childbearing age, infants and young children, the elderly, low socioeconomic groups, refugees, refugees, and populations experiencing other emergency situations). For example, iron supplementation is recognized as the only effective option for controlling or preventing iron deficiency anemia in pregnant women.

Harbige (2003) describes that the immune system is a complex set of interactive cells and molecules that have evolved to protect the internal environment, particularly against invading microbes. Food-derived fatty acids are an important source of energy for the immune system and are basic structural components of cells. They also play an important role in modulating immune responses in health and disease. Saturated and unsaturated fatty acids affect effector and regulatory functions of innate and adaptive immune cells by altering membrane composition and fluidity and by acting through specific receptors. Disorders of the balance of saturated / unsaturated fatty acids, as well as an excess of saturated fatty acids have significant consequences on the homeostasis of the immune system, contribute to the development of many allergic, autoimmune and metabolic diseases (Krishna et al, 2013).

Galli and Calder (2009) describe dietary fat (to some extent in quantity but especially in composition) as eicosapentaenoic acid (EPA) and docosahexaenoic acid (DHA)plays a role in modulating immune function and inflammatory processes. Recommendations for optimal fat intake in relation to prevention, in the first place and, to some extent, treatment of inflammatory processes can be applied to matters that should be applied to control other aspects of human health (weight control, CV function, cancer prevention) and for brain maturation and function (neonatal development, aging). Total fat consumption should not exceed $35 \%$ energy, possibly less than $30 \%$, but special attention should be paid to total energy intake, also related to anthropometric characteristics (age group, lifestyle, BMI). Recommendations should be tailored to the individual and that general requirements for certain groups, such as children and elderly subjects, have not been adequately defined.

\section{DISCUSSION}

The success of this community service activity can certainly be measured based on indicators of increasing knowledge and skills of extension participants by providing evaluations. Evaluation is done using google form.

Based on the data in Table 2 which is presented in the attachment, it is known that on average the extension participants were in the very good category. So in general, most of the counseling participants felt that community service activities through counseling on "Nutrition Awareness to Support Indonesia Ready for New Normal" were very useful for them to prepare nutrition to face the Covid-19 Pandemic.

\section{CONCLUSIONS AND RECOMMENDATIONS}

This community service program aims to provide training in new skills and knowledge to participants who are high school graduates in Tangerang City about the use of plastic waste as material for making decorative products. The target to be achieved in this program is that participants are able to identify and process the main material in the form of plastic waste into more useful decorative products. The implementation of this program is divided into 2 stages, namely the implementation stage and the evaluation stage. Equipment and support facilities, availability of space, involvement of partners, and support from the community are the main factors in the success of achieving the goals of this program. The results achieved in the form of students' ability to recycle plastic waste, process plastic waste, as well as making decorative products that are more creative and provide added value and selling points. It is hoped that with this activity students will play a role in protecting the surrounding environment by utilizing plastic waste into useful products, and become more independent in earning income. 
Proper nutrition and adequate water are essential during the COVID-19 outbreak. People who eat a balanced diet tend to be healthier with a stronger immune system and a lower risk of chronic disease and infectious diseases. So there needs to be outreach to the public regarding Nutrition Awareness to Support Indonesia Ready for the New Normal. The implementation of this counseling consists of delivering material and asking questions. The material consists of 1) nutrition conscious behavior that focuses on balanced nutrition guidelines and the role of vitamins and minerals in increasing the body's immune system; 2) Nutrition conscious behavior that focuses on the role of essential fats (EPA and DHA) in increasing the body's immune system; 3) Nutrition conscious behavior that focuses on food processing with balanced nutrition. A series of outreach activities have been well organized." This is very useful for them to prepare nutrition for the Covid-19 pandemic.

\section{ACKNOWLEDGMENTS}

We express our gratitude to Allah Subhanahu Wa Ta'ala, because for the facilities provided so that this Community Service can run smoothly. Thank you to LPPM Ottimmo Academy for providing support in the implementation of this training and mentoring. Thanks are also conveyed to the resource persons who have provided maximum counseling.

\section{REFERENCES}

BPOM. (2020). Pedoman Produksi Dan Distribusi Pangan Olahan Pada Masa Status Darurat Kesehatan Corona Virus Disease 2019 (Covid-19) Di Indonesia. Jakarta: Badan Pengawas Obat dan Makanan RI.

Centers for Disease Control and Prevention. (2020). What You Should Know about COVID-19 to Protect Yourself and Others. Cdc 314937.

Choi, Eun-suil, Na-ri Shin, Eun-im Jung, Hae-ryun Park, Hong-mie Lee, and Kyung-hee Song. (2008). A Study on Nutrition Knowledge and Dietary Behavior of Elementary School Children in Seoul. 2:308-16.

Eze, Ngozi M., Felicia O. Maduabum, Nkechi G. Onyeke, Ngozi J. Anyaegunam, Chinwe A. Ayogu, Bibian Amaka Ezeanwu, and Chiedu Eseadi. (2017). Awareness of Food Nutritive Value and Eating Practices among Nigerian Bank Workers: Implications for Nutritional Counseling and Education. Medicine. 96(10):e6283.

FAO. (2020). "Maintaining a Healthy Diet during the COVID-19 Pandemic." Maintaining a Healthy Diet during the COVID-19 Pandemic. 19(03).

Farhan Aslam, Muhammad, Saad Majeed, Sidra Aslam, and Jazib Ali Irfan. (2017). Vitamins: Key Role Players in Boosting Up Immune Response-A Mini Review. Vitamins \& Minerals 06(01).

Galli, Claudio, and Philip C. Calder. (2009). Effects of Fat and Fatty Acid Intake on Inflammatory and Immune Responses: A Critical Review. Annals of Nutrition and Metabolism. 55(13):123-39.

Habibi, Adrian. (2020). Normal Baru Pasca Covid-19. Journal.Uinjkt.Ac.Id. 4(1):197-202.

Harbige, Laurence S. (2003). Fatty Acids, the Immune Response, and Autoimmunity: A Question of n-6 Essentiality and the Balance between n-6 and n-3. Lipids. 38(4):323-41.

IFRC. (2013). Nutrition for Health and Development. France: World Health Organization.

IPPF. (2019). Novel Coronavirus Covid- 19 Infection Prevention and Control for Health Worker. Centers for Disease Control and Prevention.

Krishna, Neel K., Matthew D. Koci, and Susana Guix. (2013). Immune Responses. Nutrients Review. Vol. 9781461447.

Menteri Kesehatan. (2014). Peraturan Menteri Kesehatan Republik Indonesia Nomor 41 Tahun 2014 Tentang Pedoman Gizi Seimbang. Menteri Kesehatan Republik Indonesia. 3(2):1-46.

Muhyiddin. (2020). Covid-19, New Normal, dan Perencanaan Pembangunan di Indonesia. Jurnal Perencanaan Pembangunan: The Indonesian Journal of Development Planning 4(2):24052.

Sheng, Wang Huei. (2020). Coronavirus Disease 2019 (Covid-19). Journal of Internal Medicine of Taiwan. 31(2):61-66. 
Tsoupras, Alexandros, and loannis Zabetakis. (2020). Comment on 'Optimal Nutritional Status for a Well-Functioning Immune System Is an Important Factor to Protect against Viral Infections. Nutrients. 12(8):1-2.

Waly. (2018). Nutrition Education as a Community Perspective Approach. Canadian Journal of Clinical Nutrition. 6(2):126-31.

WHO. (2004). Vitamin and Mineral Requirements in Human Nutrition. World Health Organization. $1-20$.

WHO. (2020). COVID-19 Outbreak Eat Fresh and Unprocessed Foods Every Day Nutrition Advice for Adults. World Health Organization Regional For The Eastern Mediterranean. 19.

WHO and UNICEF. (2020). Air, Sanitasi, Higiene, Dan Pengelolaan Limbah Yang Tepat Dalam Penanganan Wabah COVID-19. World Health Organization. 1-10. 


\section{APPENDIX}

Table 1. Extension Schedule Nutrition Awareness to Support Indonesia Ready for New Normal

\begin{tabular}{lll}
\hline No & Material & Presenter \\
\hline 1 & $\begin{array}{l}\text { Nutrition conscious behavior } \\
\text { that focuses on balanced } \\
\text { nutrition guidelines and the } \\
\text { role of vitamins and minerals. }\end{array}$ & Martalena Br. Purba, \\
\hline 2 & $\begin{array}{l}\text { Nutrition conscious behavior } \\
\text { that focuses on the role of }\end{array}$ & Azizah Choiriyah, S.TP, \\
& $\begin{array}{l}\text { essential fats (EPA and } \\
\text { DHA). }\end{array}$ & \\
\hline 3. & $\begin{array}{l}\text { Nutrition conscious behavior } \\
\text { that focuses on processing } \\
\text { food with balanced nutrition } \\
\text { (Salmon Poke Bowl). }\end{array}$ & \\
\hline
\end{tabular}

Table 2. Results of Extension Evaluation

\begin{tabular}{|c|c|c|c|}
\hline No & Training Program & $\begin{array}{c}\text { Participant } \\
\text { s }\end{array}$ & Results \\
\hline 1. & $\begin{array}{l}\text { Nutrition conscious } \\
\text { behavior that focuses } \\
\text { on balanced nutrition } \\
\text { guidelines and the role } \\
\text { of vitamins and } \\
\text { minerals. }\end{array}$ & 229 & $\begin{array}{l}\text { As many as } 99 \% \text { or } 228 \text { people } \\
\text { are in the "very good" category, } \\
1 \% \text { or } 1 \text { person is in the "good" } \\
\text { category. }\end{array}$ \\
\hline 2. & $\begin{array}{l}\text { Nutrition conscious } \\
\text { behavior that focuses } \\
\text { on the role of essential } \\
\text { fats (EPA and DHA). }\end{array}$ & 229 & $\begin{array}{l}\text { A total of } 98 \% \text { or } 225 \text { people are } \\
\text { in the "very good" category, } 2 \% \\
\text { or } 4 \text { people are in the "good" } \\
\text { category. }\end{array}$ \\
\hline 3. & $\begin{array}{l}\text { behavior that focuses } \\
\text { on processing food } \\
\text { with balanced nutrition } \\
\text { (Salmon Poke Bowl). }\end{array}$ & 229 & $\begin{array}{l}\text { A total of } 96 \% \text { or } 221 \text { people are } \\
\text { in the "very good" category, } 4 \% \\
\text { or } 6 \text { people are in the "good" } \\
\text { category. }\end{array}$ \\
\hline
\end{tabular}

